SCJR 13, no. 1 (2018): 1-3

\title{
Azar Ajaj, Duane Alexander Miller, and Philip Sumpter Arab Evangelicals in Israel
}

\author{
(Eugene, Oregon: Pickwick Publications, 2016), xi + 142 pp.
}

\author{
DANIEL G. HUMMEL \\ dhummel@wisc.edu \\ University of Wisconsin-Madison, Madison, WI 53706
}

As the authors of this concise introduction remind the reader more than once, Arab evangelicals are a minority of a minority of a minority in Israel. About twenty percent of Israelis are Arab, and only ten percent of those Arabs are Christian (less than two percent of Israel's population). Arab evangelical Christians, who are viewed and view themselves as separate from the rest of the Arab Christian community, number no more than 5,000. Arab Evangelicals in Israel, written by Arab evangelical scholar Azar Ajaj and two non-Arab researchers, Duane Alexander Miller and Philip Sumpter, offers historical, institutional, and demographic information about this community. It also supplies insights into key fissures in current Israeli and Palestinian societies, such as those between Arab Israelis (Arab citizens of Israel) and Palestinians in the West Bank, between Arab evangelicals and the established Orthodox churches, and between Arab evangelicals and Messianic Jews (Jewish converts to Christianity) in Israel.

The book is divided into seven chapters. Two are co-authored and five are written by a single author. Each of the first six chapters covers an aspect of Arab evangelical history, institutions, or identity. The final chapter contains an extensive bibliography of Arabophone Christianity in Israel-Palestine. The bibliography will be valuable to anyone interested in Arab evangelicalism and extends from 1948 to 2013. While the book suffers from intermittent typographical errors and a lack of an index, it is otherwise well-produced.

Arab Evangelicals in Israel pays special attention to two contemporary institutions in particular: the Convention of Evangelical Churches in Israel and the Nazareth Evangelical Theological Seminary. The former, formed in 2005, is the Arab evangelicals' attempt to become recognized by the Israeli government as an official religion of the state, a privilege extended so far only to those churches which existed in the land before 1948. Such official recognition would allow church authorities to administer marriages, burials, wills, and other legal processes. Virtually all Arab evangelical churches in Israel (some thirty-five or so) 
belong to the CECI, apart from five churches of the Closed Brethren. The CECI has yet to achieve official status in Israel.

The second institution, the Nazareth Evangelical Theological Seminary, was founded in 2007, though Baptist education in Israel extends back decades. Ajaj, a lecturer and administrator at NETS, casts the school as an evangelical alternative to the more liberation-oriented Bethlehem Bible College (in the West Bank). The latter, Ajaj writes, teaches "Palestinian contextual theology" (p. 28). This theology is highly critical of Israel and probably best known to Western scholars through the writings of Naim Ateek and the biennial Christ at the Checkpoint event. (On this topic Ajaj draws on the work of Uwe Gabe.) Operating in the context of Israeli society at the cross-section of Arab, Israeli, and evangelical identities, NETS is less strident in its criticism of Israel and less sanguine about the possibility of Muslim-Christian coexistence in the future.

These two institutions and the challenges they face are a microcosm of the broader concerns of Arab evangelicals in Israel. Ajaj observes that while Arab evangelicals are less alienated in Israeli society than are Arab Israelis generally, they worry about "the radicalization of many of its Jewish citizens" and their "inability to identify with the Jewish state" because of discrimination and a national ideology that celebrates Jewish migration to Zion (pp. 10, 32). At the same time, Ajaj reports that among Arab evangelical pastors, attitudes toward Islam are skeptical. "Our respondents do not appear to agree," writes Ajaj, "with the Western conviction that Islam (correctly practiced) is peaceful and tolerant" (p. 58). The book offers a number of explanations for perceptions that Arab evangelicals are outsiders. Evangelical Christianity is largely foreign to Arabic culture; there are historical tensions between Christians and Muslims, and recently there has been a decline in Arab nationalism, which had subsumed religious differences between Muslims and Christians under a shared ethnic identity. The prospect of a future Palestinian state governed by Sharia law (which currently undergirds the Palestinian Authority's legal system) troubles Arab evangelicals as well.

The Arab evangelical experience differs on these counts from the more established Arab Orthodox churches, most of which remain opposed to evangelicals and see the smaller community as a disruptive force. They discourage religious conversion, in contrast to Arab evangelicals, who actively seek converts. This has led to confrontations not only with Muslim and Jewish authorities, but with Orthodox leaders. Miller, writing about Christians from a Muslim background, reports that those Muslim converts to evangelical Christianity whose conversion becomes public are often severely ostracized. Moreover, such converts are almost uniformly refused membership in Arab Orthodox churches. This phenomenon is rare, but the different stances toward conversion indicate the wide chasm between Arab evangelical and Arab Orthodox Christians.

Arab evangelical relations with Messianic Jews are another area beset by deep problems. Ajaj laments a lack of interest in such relations by the Arab evangelical pastors he interviewed, likely out of resignation that political, social, and theological differences are too wide to justify expending energy on attempts at rapprochement. In particular, virtually all Messianic Jews believe that the state of 
Israel is a fulfillment of biblical prophecy and that Jews have a distinct role to play in history apart from gentile (including Arab) Christians. These beliefs have "become so central in the theology of many Messianic Jews," writes Ajaj, that any divergent view is deemed by these Jews as wrongheaded or even antisemitic (p. 78). Yet, as Ajaj points out, the social position of Arab evangelicals and Messianic Jews is in many ways similar. Both are religious minorities at the margins of Israeli society. Despite differences in eschatology and some other theological topics, both are essentially evangelical Christians, and both have a vested interest in making Israeli culture more pluralistic. Ajaj concludes by calling for a "healthy dialogue" that transcends the Arab-Jewish divide in Israel (p. 90).

The authors also consider the relationship of Arab evangelicalism to Western (American and European) churches. Historically, the connections are quite close. The first Arab Baptist missionary in Palestine was baptized at First Baptist Church of Dallas in 1909. Baptist missionaries to Palestine were instrumental in building the Arab evangelical community, founding churches and orphanages in Arab communities in and around Nazareth. The Arab-Israeli War in 1948-49 decimated the Arab Christian population within Israel. Afterward, western missionaries moved to "indigenize" local churches by promoting Arab leadership, which later was called "contextualization." This included less dependency, both financial and theological, on Western evangelicals (p. 62). The close association between Western evangelicals and Christian Zionism has also prompted Arab evangelicals to try to distance themselves, even as they collaborate with (and depend financially on) American and European seminaries and missionaries.

Undoubtedly, one accomplishment of Arab Evangelicals in Israel is bringing to the fore a community that most Americans and Europeans-including many scholars - are unacquainted with. Their small numbers and marginal social position notwithstanding, Arab evangelicals sit at the intersection of numerous fault lines in Middle Eastern and Israeli-Palestinian history. Arab Evangelicals in Isra$e l$ offers a sympathetic introduction to this community that awaits more sustained and thorough treatment. 